\title{
Foreign Students' Social Adaptation to the Education Environment of a Higher Educational Institution: By the Example of S. Seifullin Kazakh Agro Technical University
}

\author{
Ainur Kanapiyanovna Abdina \\ Horlan Saduakasovna Abdildina \\ Aiman Galimjanovna Gappasova \\ Margarita Kabdulayevna Kakimzhanova \\ Dmitriy Valerievich $\mathrm{Ni}$ \\ Torgyn Meyrhanovna Sadykova \\ Email: agun.katu@gmail.com, rita_k79@mail.ru
}

\section{S. Seifullin Kazakh Agro Technical University, 62 Prospekt Pobedy, Astana, Republic of Kazakhstan}

Doi:10.5901/mjss.2015.v6n5p184

\section{Abstract}

\begin{abstract}
The article provides the data of the research project conducted among the students of S. Seifullin Kazakh Agro Technical University (KATU). The research objective is to estimate the level of foreign students' social adaptation to the education environment of the higher educational institution within the program of academic mobility. The research of the problems of foreign students' social adaptation to the Kazakh Higher School has always been the subject of scholarly attention in the theoretical as well as in the applied aspect. Until now, the national scientists have not studied the problem of foreign students' social adaptation at Kazakh higher educational institutions. It is necessary to close this gap, because the teaching of foreign students is becoming the most important part of the education system all over the world. Problems of academic mobility have been widely discussed by the global university and academic community. Scientists have been addressing the issues of the university viable horizons in the 21st century, intercultural communication, migration and internationalization of the higher education. Besides, the scholarly discourse places special emphasis on one more peculiarity of academic mobility in the western education system - the cultural and communication strategies. In the post-soviet education system, adjustment of education programs of academic mobility, i.e. care of adaptation of education technologies, was considered a major problem, whereas leading world universities address the problems of personal adaptation to the education environment, and that has become the issue number one in the modern world. Using the methods of literature review and sociological survey, we prove the hypothesis that the problems of personal adaptation to the education environment are the most important factors for the system of academic mobility.
\end{abstract}

Keywords: academic mobility, social adaptation, education environment, foreign students.

\section{Introduction}

The timeliness of the topic is determined, on the one hand, by the issues of the inclusion of Kazakhstan in the single world education environment, and on the other hand, by the necessity to promote Kazakh educational services at the global market.

Integration of the theoretical and applied aspects of the study of foreign students' adaptation to the Kazakh Higher School appears to be an extremely burning and important issue in the development of the modern higher education that may be observed through its internationalization. We have dwelled on the role of academic mobility in the process of education internationalization in our previous works (Abdina and Kakimdzhanova, 2014).

The extension of academic mobility within various forms of teaching methods at Kazakh universities requires active participation on the part of professors, psychologists, sociologists, social and administrative workers in order to provide high quality educational services. According to the Agency for Statistics of the Republic of Kazakhstan, the number of foreign students in Kazakhstan comprises 10.4 thousand students, and a significant part of them studies agricultural and technical specialties (Abdina, 2015). 
Foreign students from Afghanistan, Kyrgyzstan, China, Mongolia, Russia, Tajikistan, Turkmenistan, and Uzbekistan study at KATU. Most of them choose agricultural and technical specialties.

The objective of the research is to estimate the level of foreign students' social adaptation to the education environment of the university within the program of academic mobility.

The object of the research is the education environment of KATU.

The subject of the research is the influence of social adaptation on the process of graduating by foreign students.

The hypotheses of the research are as follows:

1. Foreign students face a psychological barrier while communicating with other students and professors.

2. The language barrier hinders foreign students' social adaption to the education environment.

3. The quality of social services influences the level of students' social adaptation to the environment.

4. The quality of education services affects the level of students' social adaptation to the environment.

\section{Material and Methods}

We have used literature review and sociological survey as research methods.

\subsection{The literature review}

The literature review of the topic shows that the appearance and development of the academic mobility system can be explained by a number of reasons, of which the most important ones are: firstly, changes in the education systems' infrastructure in all parts of the world; secondly, the necessity of radical changes in the education system that is the demand of the rapidly changing environment. The majority of governments make great allocations for improvement of the higher education quality. Higher educational institutions in some countries consider the amount of foreign students as an indicator of attractiveness of the education system, i.e. the more foreign students study at the universities, the more prestigious the higher education of the country is (Teichler and Ulrich, 2001).

Moreover, the economic component is of no less importance for academic mobility. Nowadays in Europe, education is treated as a high-yield business and therefore, for the education suppliers-public and private institutionsforeign students are seen as an extra source of profit. In "Education indicators in focus" (OECD, 2013), the following information is given: in Canada, the profit that was gained in 2010 from education and accommodation of foreign students (8 billion Canadian dollars) was more than the overall Canadian export of rough aluminum ( 6 billion Canadian dollars) or the export of helicopters, airplanes, and spaceships ( 6.9 billion Canadian dollars) (OECD, 2013).

In the USA, internationalization of education is an essential factor of the state policy and university strategies. Total government revenues from preparatory courses for foreign students are no less than USD 14 billion a year.

The leading world universities put an emphasis on one more important aspect of academic mobility-the long-term effect from foreign students' education on the state economy, i.e. those students that stay in the country after their graduation greatly influence the labor market. In other words, students' international mobility serves as an important channel for highly qualified immigrants. Studies that were conducted in Australia, Great Britain, Canada, Czech Republic, and France have proved this hypothesis (Suter and Jandl, 2006).

Serious changes in the growth of international students' mobility took place at the end of 1990s and the beginning of 2000s, when it became prestigious to study abroad, especially in English, in such countries as China and India.

According to the UNESCO research, motivation of individuals, the economy, and the society, which is aimed at the increase of the education level, requires greater participation in various spheres of education activity, regardless of people's age (UNESCO Institute for Statistics, 2001).

At that time, exchange programs became widespread. By 2000, the number of foreign students who participated in exchange programs between OECD countries had increased by $16 \%$.

"In total, the number of students that studied in higher educational institutions outside their countries increased by more than three times-from 1.3 million in 1990 to 4.3 million in 2011. During the global economic crisis, in spite of some observers' expectations, there was no decrease in the amount of foreign students" ("Education indicators in focus", OECD, 2013).

In 1999, the Australian international organization dealing with the student admission into 38 state universities predicted that the demand for higher education would triple until 2025 in comparison with 2000. Nowadays, Asia possesses the greatest growth potential in this sphere. It is expected that in $2025,70 \%$ of the world demand for higher education and $50 \%$ of the demand for international higher education will be provided by Asian countries, especially India and China (Böhm and Anthony, 2014). 
In academic literature, issues of foreign students' social adaptation to education environment are mostly connected with the problems of inclusive education and are highlighted from the perspective of physically challenged students' adaptation to the education environment. As for foreign students' adaptation to the new education environment, there are some interesting studies dedicated to this topic. They cover such issues as the influence of social networks on foreign students' adaptation to the education environment (Cao and Zhang, 2012); sociocultural and psychological adaptation of students (Vasiakin et al., 2015); contingence of the academic progress and social adaptation. Some studies deal with such questions as the elaboration of models of friendly behavior among foreign students (Iversen, 2009); cross-cultural adaptation of students (Lewthwaite, 1997); mutual adaptation of foreign students and scientists for the stable development of international education (Tran, 2008), as well as with the questions of a cultural shock and stress that foreign students experience while changing the education environment (Zhou et al., 2008). All that studies are of great scientific and academic interest.

\subsection{The sociological survey}

The sociological survey was conducted based on the research program that was adopted for this topic. We had defined objectives and tasks, the sample frame, hypotheses, the object and subject of the research that have been stated in the introduction to this article. We had drawn up a questionnaire, which dealt with the topic under discussion from different perspectives. Judging by the research depth of the problem of foreign students' adaptation to the education environment of the university, our study was of an exploratory nature. The data collection was provided by interrogating students and interviewing the faculty. The research is of a spot nature; however, considering the questions that occur in the course of the study, we assumed that a second opinion poll with a wider research field would be required. Below, we provide the results of our sociological survey represented in charts.

\section{Results}

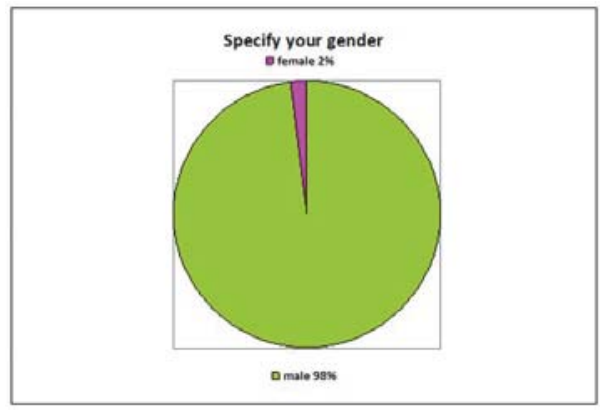

Chart 1. Specify your gender

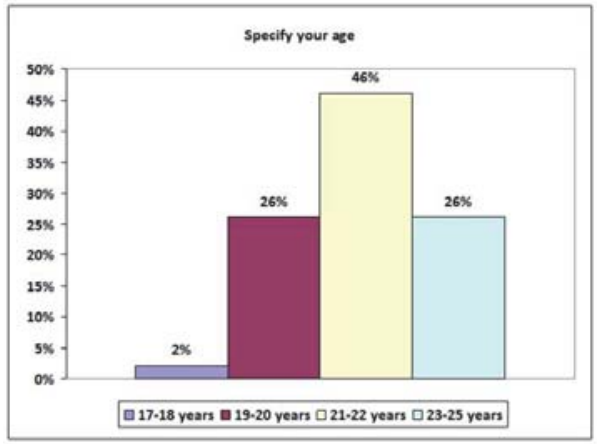

Chart 2. Specify your age 


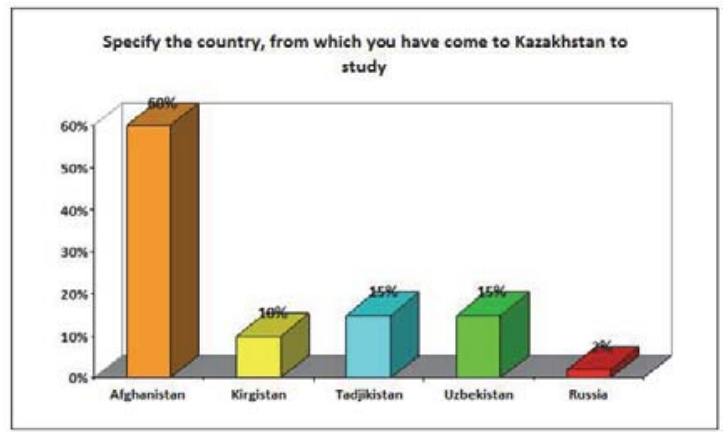

Chart 3. Specify the country, from which you have come to Kazakhstan to study

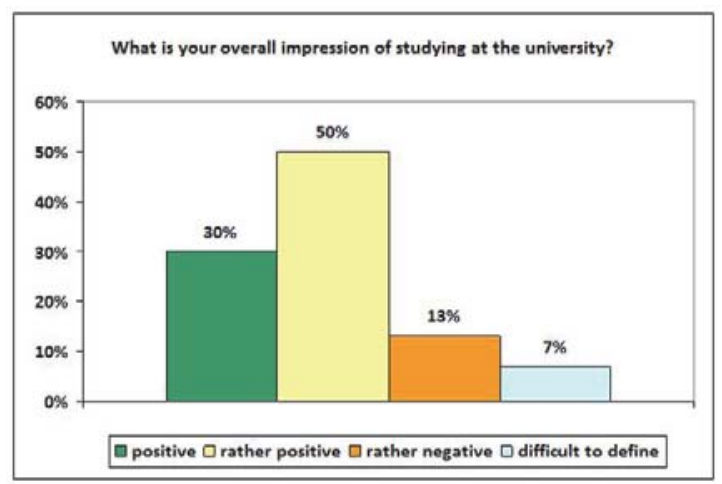

Chart 4. Specify your overall impression of the studying process at the university

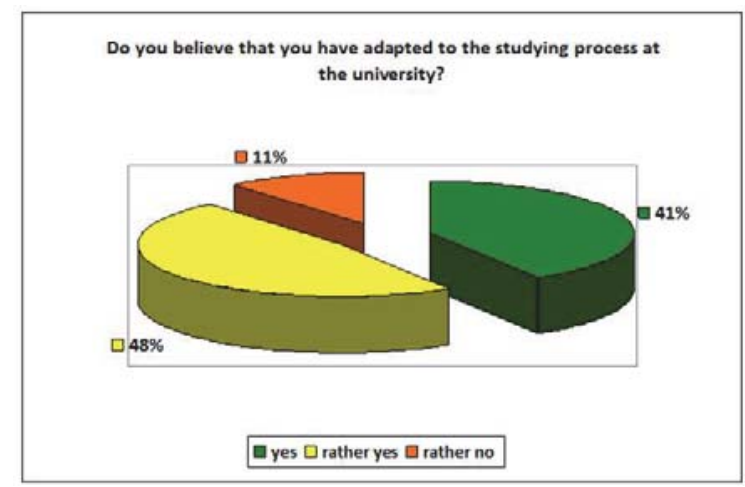

Chart 5. Do you believe that you have adapted to the educational process in the university? 


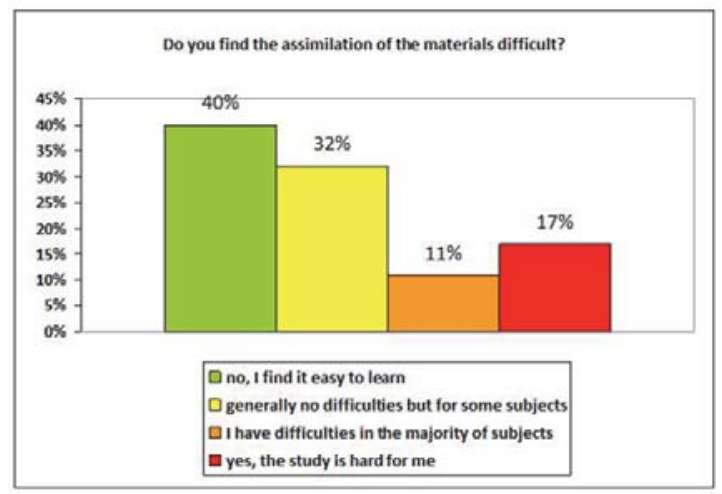

Chart 6. Do you find the assimilation of the materials difficult?

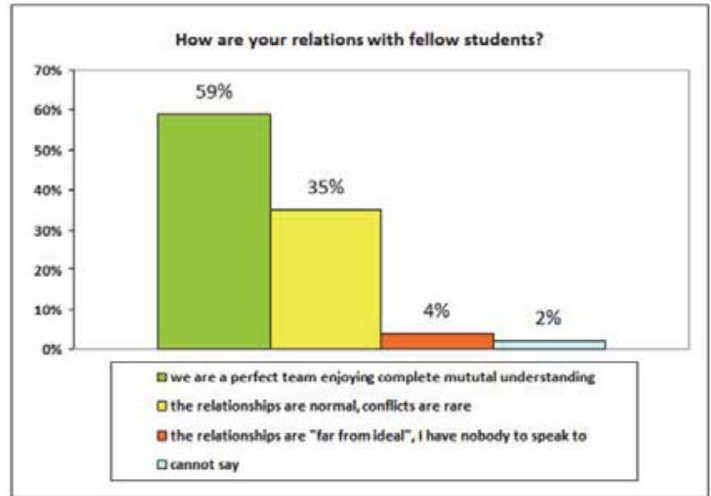

Chart 7. How are your relations with fellow students?

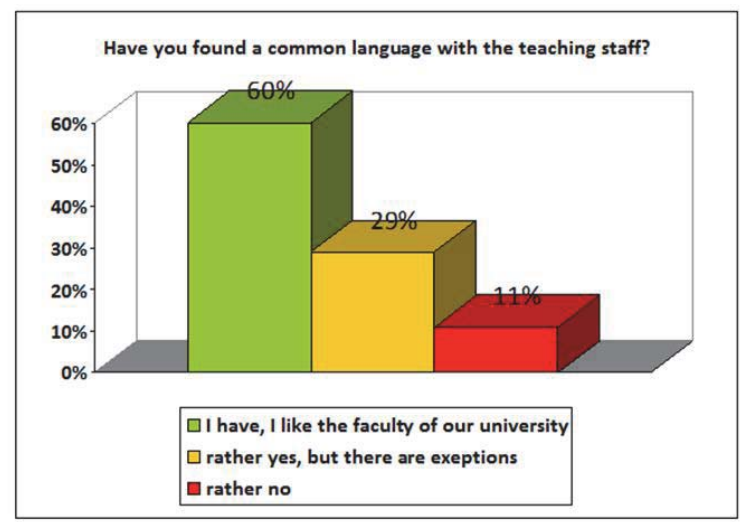

Chart 8. Have you found a common language with the teaching staff? 


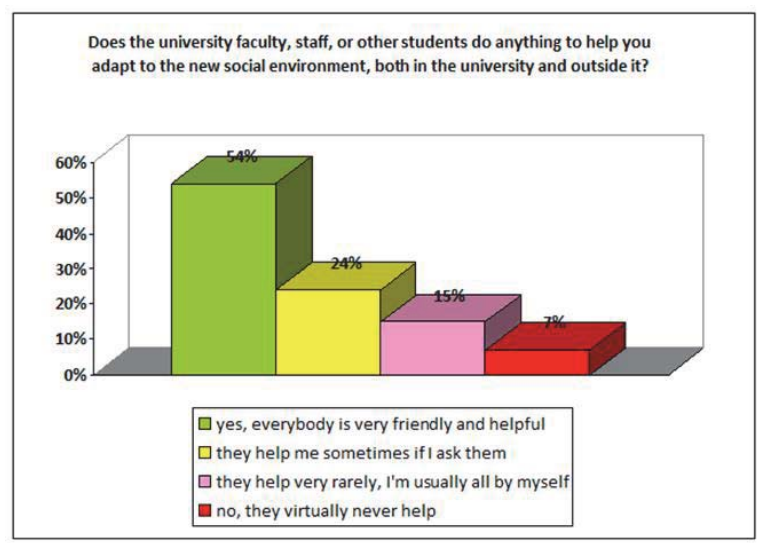

Chart 9. Does the university faculty, staff, or other students do anything to help you adapt to the new social environment, both in the university and outside it?

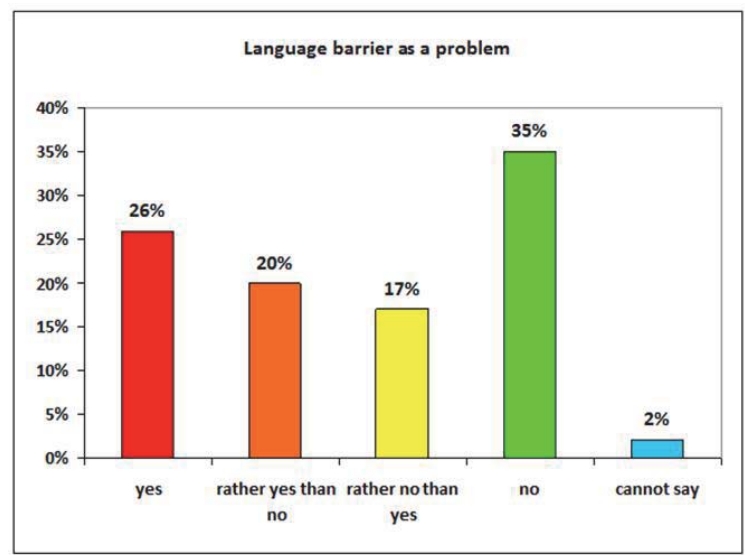

Chart 10. Do you face the problem of understanding your teachers and other students because of the language barrier?

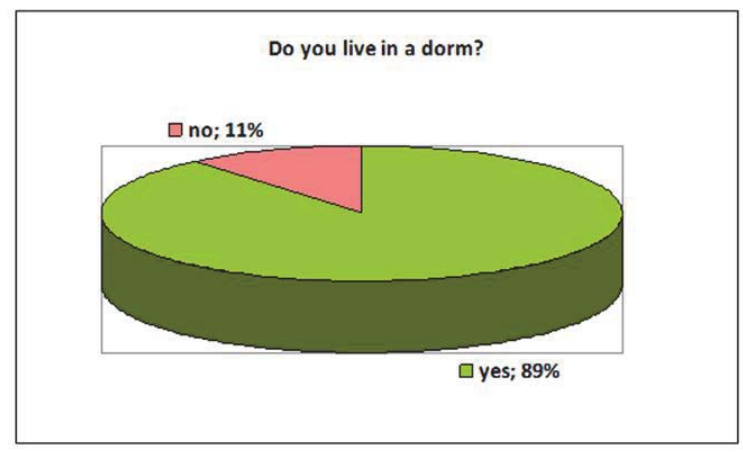

Chart 11. Do you live in a dorm? 


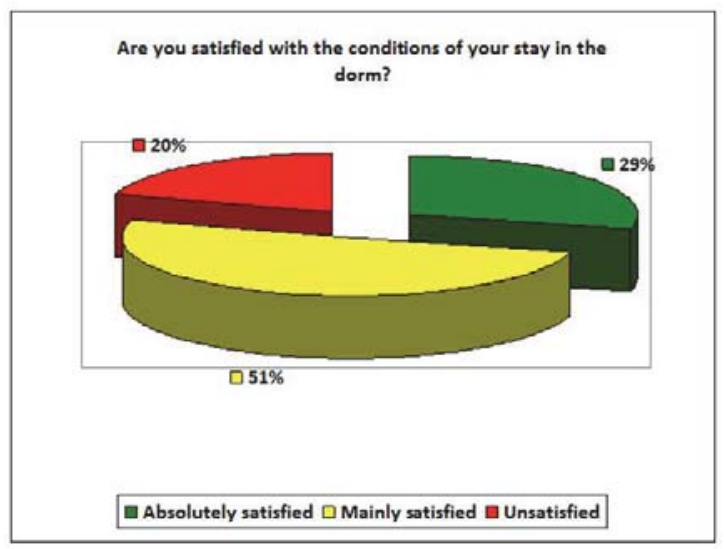

Chart 12. Are you satisfied with the conditions of your stay in the dorm?

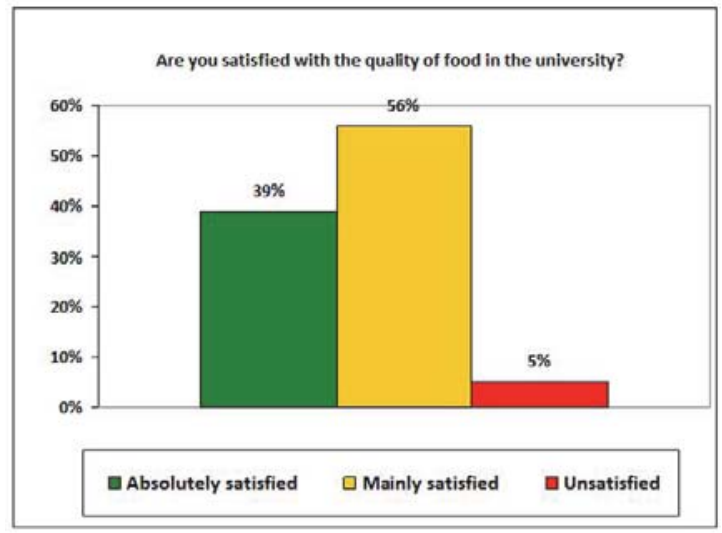

Chart 13. Are you satisfied with the quality of food in the university?

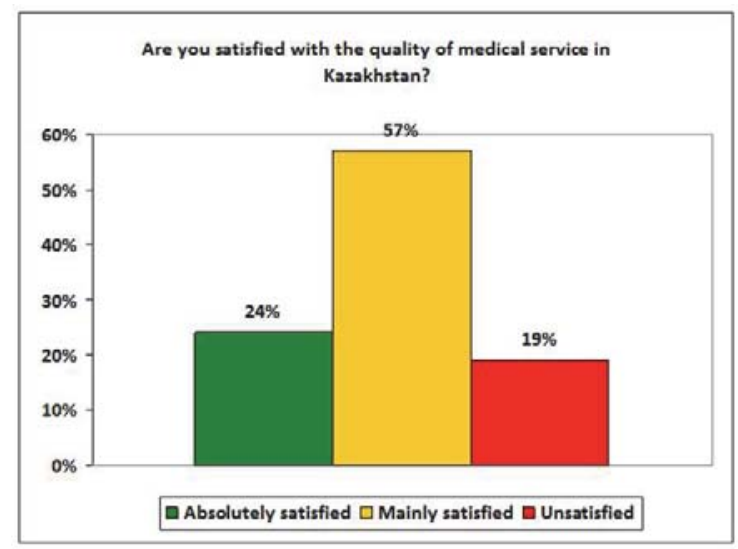

Chart 14. Are you satisfied with the quality of medical services in Kazakhstan? 


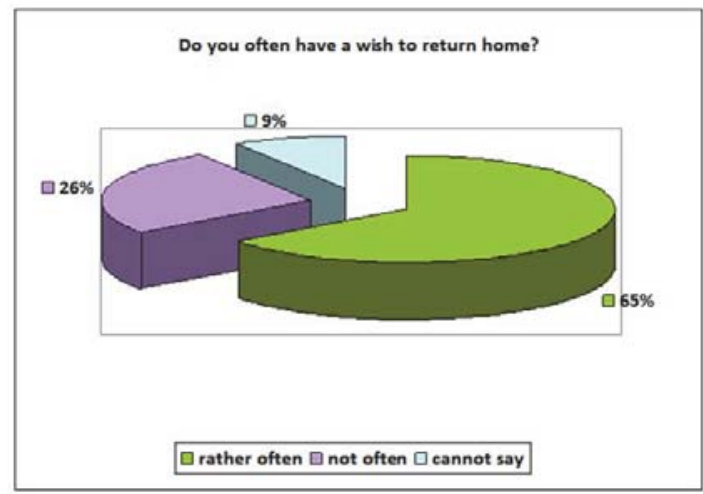

Chart 15. Do you often have a wish to go home?

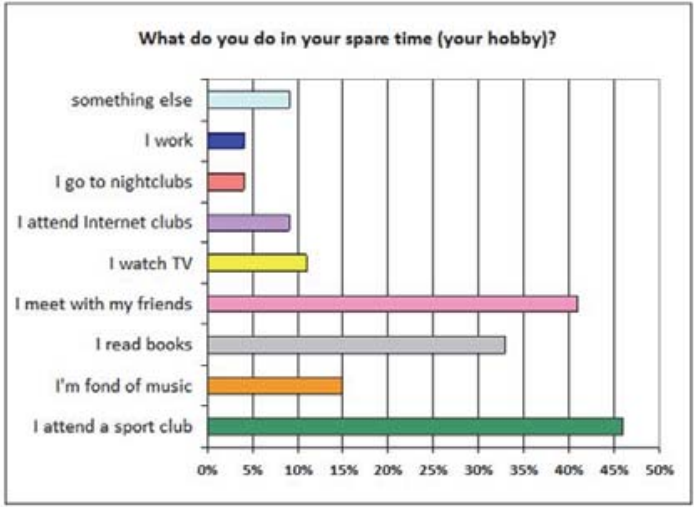

Chart 16. What do you do in your spare time (your hobby)?

\section{Discussion}

As a result of our research project, we interviewed about $50 \%$ of foreign students of our university. Chart 1 reflects the percentage of those boys and girls who participated in the survey. Noteworthy is the fact that among the surveyed students, only $2 \%$ were female, and the other $98 \%$ were male. This fact reveals another interesting problem, and in our further research, we would like to consider the gender features of academic mobility.

The respondents' age was in line with expectations, that is, all those interviewed were young people up to 25 years. In Chart 2, you can see that the majority of the students are aged 21-22 years.

Our poll gripped students from Afghanistan, Kyrgyzstan, Russia, Tajikistan, and Uzbekistan. Chart 3 shows that the approximate percentage was: 60\% from Afghanistan, 10\% from Kyrgyzstan, approximately 15\% each from Tajikistan and Uzbekistan. Russia is represented by $2 \%$ of the students. If you correlate this data with answers to the question of gender, then $2 \%$ of female students are girls from Russia. In this case, all representatives of Central Asia are male, which possibly points at gender problems both in the educational environment and in social mobility in the region. In subsequent research, it makes sense to pay attention to the relevance of gender and regional aspects of academic mobility.

Several items of our questionnaire referred to the hypothesis asserting the thesis on foreign students' satisfaction with the quality of educational services. As for the question about the overall impression about the university (Chart 4), over $80 \%$ of students responded positively, $15 \%$-negatively, and approximately $5 \%$ of students could not answer this question. The issue of adaptation to the educational process at the university, to the schedule, lectures length, place of their conduct, was found positive by the vast majority of students (90\%). Only five students were not sure that they had adapted to the educational process (Chart 5). Finally, the question about the difficulties in learning revealed the following: 
about $40 \%$ of the students had no difficulties, $30 \%$ had difficulties with only some subjects, $10 \%$-with the majority of the subjects, and $20 \%$ of the students admit that studying is hard for them (Chart 6). In other words, the overall impression from the university, adaptation to studying and learning gave an overall picture of the students' satisfaction with the study at the S. Seifullin Kazakh Agro Technical University.

Some of the questionnaire questions concerned the problems of foreign students' psychological adaptation to the educational environment of the university. As seen from Chart 7, the absolute majority of the students (93\%) to the question "How are your relations with the fellow students?" said "We have an excellent, friendly team, enjoying complete mutual understanding" and "The relations are normal, conflicts are rare." Only two students believed that the relationships were far from perfect, and one student could not answer this question. Chart 8 shows that the question "Have you found a common language with the teaching staff?" also revealed the level of foreign students' psychological comfort. $61 \%$ of respondents liked the university faculty, $28 \%$ were also satisfied with the faculty of the university, with rare exceptions, and only $11 \%$ of the students believed that relations with teachers were not good at all. Chart 9 demonstrates the responses to the question, whether the university faculty, the staff, or other students helped the student somehow in adapting to the new social environment, both at the university and outside it. Most students also responded positively; $54 \%$ of respondents believed that everyone who surrounded them was very friendly and always tried to help, $24 \%$ said that they would be helped if they asked. However, $15 \%$ of respondents believed that they were helped very rarely, and about $7 \%$ of students indicated that nobody helped them at all. It is possible that those students who felt that they were rarely helped did not ask for help, or did not need it, since about $78 \%$ still believed their environment was quite comfortable.

Another question in the questionnaire concerned the hypotheses of the language barrier relevant for foreign students. The question read, "Do you face the problem in understanding your teachers and other students because of the language barrier?" That is, the formulation of the question focused on the student's subjective perception of his language proficiency (Kazakh, Russian, or English, depending on the language of the study). Chart 10 shows that $46 \%$ of students admitted that they had problems due to the language barrier, about $52 \%$ believed that they had no such problems, and $2 \%$ did not answer this question (perhaps due to the language barrier itself).

The teachers lecturing foreign students believed that in most cases, the students had a poor command of the language of the study. In response to the last question of the questionnaire, which encompasses the chance to express an opinion on the improvement of the comfort level in the educational environment, students expressed a desire to attend language courses if they would be available.

Several questions of the questionnaire were related to the thesis of foreign students' satisfaction with the quality of social services. These include accommodation, food, and medical care. As the survey revealed, about $90 \%$ of respondents lived in dormitories (student campus) (Chart 11). Of these, $80 \%$ were satisfied with the conditions of their stay in the dorm, and $20 \%$, respectively, were not satisfied (Chart 12). The next question on the quality of the food in the university dining rooms and cafes had mostly positive reaction of the respondents. About $96 \%$ of the respondents indicated that they were satisfied with the quality of the food at the university (Chart 13). Finally, the quality of medical services provided to students, both at the university and beyond it, was estimated at the ratio about $80 \%$ to $20 \%$. That is, most students were satisfied with the quality of medical services in Kazakhstan (Chart 14). While the nutrition organization was assessed positively, the housing conditions and medical aid quality left the fifth part of the questioned students unsatisfied.

Another issue related to the personal psychological adaptation to the environment read, "Do you often have a wish to return home?" This wording indicates the latent nature of the issue. Despite the answers to previous questions were positive, the constant desire to "go back home" witnessed the personal psychological discomfort. It is widely known that the feeling of "being home" suggests a comfortable zone and, accordingly, feeling "out of home" is tantamount to being outside the comfortable zone. Chart 15 shows that $60 \%$ of the respondents quite often had a desire to return home. In turn, $26 \%$ of students did not often experience such a desire. $14 \%$ of respondents could not answer this question.

Chart 16 shows the results of the question concerning the students' leisure. Asking, "What do you do in your spare time?" we tried to determine how much the free time could influence the adaptation to the new educational environment. The issue assumed multiple-choice response, so the analysis focused on the frequency of likely responses selection. The most popular one was the sport clubs membership, then companionship and attending various events. Reading books and listening to music took, respectively, $3^{\text {rd }}$ and $4^{\text {th }}$ positions. Then, only a few students chose Internet clubs, TV, nightclubs. In addition, several students said that they loved to play football and one student-to do science, although the latter position, however, is not the leisure but the learning process. Responses to this question show that most students chose mass events that were largely organized within the walls of the university, which is an important aspect of students' social adaptation. Personal hobbies, books and music were second to mass events. Only two students pointed out that in 
their free time they were busy working. Most likely, it points to the fact that students were busy studying all day (full-time) and did not have the opportunity to combine study and work.

And finally, the last question "What university issues need to be addressed in the first place, in order to make your stay here more comfortable?", as noted above, asked the students to express their own opinions about the issues they faced and on the possibilities for their solution. The most common students' wish is the acquisition of the international status by our university, respectively, with a diploma of international acceptance. In addition, students thought that courses of Kazakh, Russian, and English languages could contribute to their comfortable stay in the new educational environment. The sparsely occurring responses include the improvement of the examination system, the elimination of students' dishonesty or bad faith, the use of modern materials and teaching methods, as well as the creation of greater variety of students ' leisure options.

\section{Conclusion}

Considering the data of the conducted research, we may conclude the following.

The first hypothesis about the phenomenon that foreign students try to overcome a psychological barrier while communicating with professors and other students has been partially proved. The absolute majority of the students (93\%) confirmed that they were in a state of total mutual understanding with the student environment; $89 \%$ of respondents mentioned a sufficient comfort level while communicating the faculty; $78 \%$ of respondents mentioned the goodwill of the people around and their readiness to help adapt to the education environment. Meanwhile, $60 \%$ of the students often felt the desire to go home that implied the existence of a certain psychological discomfort that foreign students felt while integrating in a new education environment.

The second hypothesis about the language barrier that hinders foreign students' social adaptation has also been partially proved as $46 \%$ of the students admitted that they had problems because of the language barrier. Interviewing the professors that teach foreign students in our university revealed that in the majority of cases, students had poor language competence. As a result, the following situation may take place in the class. A professor who is highly interested in student's mastery of the course begins to explain the material using the language that is better understood by foreign students rather than the language of the tuition. This reveals another problem-the problem of teaching in polylingual groups that has become one of the trends of the modern education system in Kazakhstan. The desire of the students who took part in our poll to attend courses of the Kazakh, Russian, and English languages emphasizes the existing problem of the language barrier in the process of foreign students' social adaptation.

The third hypothesis that is connected with the thesis that the quality of social services influences the level of adaptation to the education environment is very true. $80 \%$ of the students were satisfied with the living conditions of the campus. $93 \%$ of the respondents were sure that the quality of nutrition at cafes and dining-halls of the university were at an adequate level. $80 \%$ of the students were satisfied with the quality of medical services provided in Kazakhstan.

The fourth hypothesis related to the influence of the education services' quality on the level of foreign students' social adaptation is also totally true. $80 \%$ of the students had the most favorable impression of the university's education environment. $90 \%$ of the respondents supposed that they had adapted to the education process with all accompanying elements. As for the acquisition of the educational material, students' opinions vary in this issue. Around $70 \%$ of foreign students did not face any difficulties with material acquisition or had some problems with just a few disciplines, whereas around $30 \%$ of the students experienced problems with the majority of subjects or admitted that education was hard for them. As questions about the quality of education services are related to the foreign students' adaptation to them, we find it fair to conclude that the hypothesis has been confirmed.

The study of the students' academic mobility requires special attention, because we are talking about the creation of equal conditions for all individuals in the right for obtaining education and self-fulfillment in the circumstances of the globalizing world. Academic mobility promotes the development of individual practical skills that allow not only adapting to and transforming the social environment, establishing personal and business international contacts, but also to fulfill oneself in a particular occupation, demonstrating professional competence. Thus, summing up our research project, we affirm that problems of individual adaptation to the education environment serve as the most important element of students' academic mobility.

\section{References}

Abdina A., \& Kakimjanova, M. (2014). Academic mobility: social adaptation of foreign students of higher agricultural educational institutions Republic of Kazakhstan to educational environment of the country. Vestnik nauki KazATU im. S.Seifullina - Vesrnik 
nauki of S. Seifullin KATU, 4, 42-46 [in Russian].

Abdina, A. (2015). Akademicheskaia mobil'nost' $\mathrm{i}$ internatsionalizatsiia obrazovaniia [Academic mobility and internationalization of education]. Proceedings of the $2^{\text {nd }}$ All-Russian Conference "Sotsial'no-professional'naia mobil'nost' v XXI veke" [SocioProfessional Mobility in the 21st Century], Yekaterinburg, 28th -29th of May, 2015, pp. 5-10 [in Russian].

Böhm, A. (2014). Global Student Mobility 2025: Analysis of Global Competition and Market Share. IDP Education Pty Ltd. Retrieved 2014.

Chan, I. (2006). Psychological adaptation of Mainland Chinese Female International Students: A Phenomenological Inquiry (PhD thesis). University of Tennessee. Retrieved from http://trace.tennessee.edu/utk graddiss/1932.

Chaoping Luo, Ning Zhou, Qiong Zhai, Zhenglin Cao (2014). Cross-Cultural Adaptation of Foreign Students in Chinese University: Based on Network of Social Support. Cross-Cultural Communication, Vol. 10, 1. http://www.cscanada.net/index.php/cccl article/view/j.ccc.1923670020141001.4018.

Data of the Agency for Statistics of the Republic of Kazakhstan. Retrieved from http://www.stat.gov.kz.

Hajara, M. (2014). An Analysis of Acculturative Stress, Sociocultural Adaptation, and Satisfaction among International Students at a Non-Metropolitan University (PhD dissertation). Retrieved from http://digitalcommons.wku.edu/diss/63 .

Iversen, G.I. (2009). Social adjustment and friendship patterns of international students (A study of Norwegian students studying abroad) (Master's thesis in psychology). Retrieved from http://munin.uit.no/bitstream/handle/10037/2425/thesis.pdf.

Lewthwaite, M. (1996). A study of international students' perspectives on cross-cultural adaptation. International Journal for the Advancement of Counselling, 1996/1997, Vol.19, 2, 167-185.

Ling Cao and Tingting Zhang (2012). Social Networking Sites and Educational Adaptation in Higher Education: A Case Study of Chinese International Students in New Zealand. The Scientific World Journal, Vol. 2012, Article ID 289356. Retrieved from http://www.hindawi.com/journals/tswj/2012/289356/.

Sumer, S. (2009). International Students' Psychological and Sociocultural Adaptation in the United States (PhD dissertation). Georgia State University. Retrieved from http://scholarworks.gsu.edu/cps_diss/34.

Suter, B., \& Jandl, M. (2006). Comparative Study on Policies towards Foreign Graduates: Study on Admission and Retention Policies towards Foreign Students in Industrialized Countries (Report). Vienna: International Center for Migration Policy Development.

Teaches for tomorrow's schools: Analysis of the world education indicators (Report) (2001). OECD World Education Indicators Programme. UNESCO Institute for Statistics.

Teichler, U. (2001). Why Mobility? What We Know and What We Do Not Know. - In: International Programme Office for Education and Training (ed.): From Individual Development to Employability. Stockholm: International Programme Office for Education and Training.

Tran, L.T. (2008). Mutual Adaptation of International Students and Academics for the Sustainable Development of International Education. Retrieved from http://ro.ecu.edu.au/cgi/viewcontent.cgi?article=1057\&context=ceducom.

Vasiakin, B., Berezhnaia, M., Pozharskaia, E., \& Deberdeeva, N. (2015). Adaptation of Graduates and Students of Regions to Education in Higher Education Institutions of Russia by Means of Social-Psychological Training. Review of European Studies, Vol. 7, 3. Retrieved from http://www.ccsenet.org/journal/index.php/res/ article/view/45891

Westwood, M., \& Barker, M. (1990). Academic achievement and social adaptation among international students: A comparison groups study of the peer-pairing program. International Journal of Intercultural Relations. Vol. 14, 2, 251-263.

Wilson, G.P. (2011). Fitting-In: Sociocultural Adaptation of International Graduate Students. Dissertation \& Theses Collection. Paper AA/3457225. Retrieved from http://scholarsarchive.jwu.edu/dissertations/AAI3457225.

Zhou, Yu., Jindal-Snape, D., Topping, K., \& Todman, J. (2008). Theoretical models of culture shock and adaptation in international students in higher education. Retrieved from Studies in Higher Education http://dx.doi.org/10.1080/03075070701794833. 